\title{
Riverside sustainability - Overcome problems and reliable approaches
}

\author{
Irma Novrianty Nasution ${ }^{1 *}$, Syahreza Alvan ${ }^{2}$ \\ ${ }^{1}$ State University of Medan, Civil Engineering Department, Medan, North Sumatera, Indonesia \\ ${ }^{2}$ State University of Medan, Civil Engineering Department, Medan, North Sumatera, Indonesia
}

\begin{abstract}
The growth of population is a feature behind the urbanization. The city's facilities are an attraction for migrants to work and live. It has led to the emergence of urban problems in terms of providing employment, legal settlements, and livable formal housing. The inability of the lowincome community economically will lead it to live in area on riverside, railroads, and Chinese cemetery. Then, it will be turned into a slum area. Kampong Aur is part of a slum area of Medan, also have the same problem. Therefore, it is the importance of research. The data collected by an observations, previous studies, journals, planning documents, and aerial photographs. The data obtained were analyzed and elaborated using qualitative descriptive method. The results show that Kampong Aur can be observed from the land tenure, physical environment, livelihood, public facilities, and socio-cultural conditions. It is a unique type of settlement with consists of formal and informal housing built side-by-side. Informal settlements are usually located along the river borderline. And it is categorized into slum settlements. Originally, slums need to be managed integratedly and well organized, improvement or relocation, with a humane and sustainable approach through the participation of all parties. In this way, participatory and cooperative designs are the reliable approaches that can be applied to the settlement conditions in Kampong Aur.
\end{abstract}

\section{Key Words}

riverside, environment, sustainable, settlement

\section{Introduction}

Rapid urbanization is happening across Asia, with more and more people in need of housing. Providing adequate housing to everyone in the cities is not an impossible goal. It's possible to solve the serious housing problems, if it can begin to see urban poor settlements not as problems, but as sources of energy and important contributions to the production of housing. And it's possible if it can look at the poor not as beneficiaries of someone else's ideas, but as the primary actors at the centre of their own development.[1]

\footnotetext{
${ }^{*}$ Corresponding author: irma_nst11@yahoo.com
} 
Over one billion people live in 'squatter', 'slum', or 'informal' housing settlements globally. This population is expected to double by 2030, making such settlements the major form of urban housing.[2] And more than a half of them live in Asia.[3] These settlements often characterised by unclear tenure status, poor basic services, inadequate construction an over crowded living conditions, are an urban emerging due to various social, economic, and political factors. [4] The most obvious place to choose is unauthorized public land, such as: river banks, fire access lanes, railway yards, and even Chinese cemeteries.[5]

According to Kamil (2017), in 2025 nearly $60 \%$ of people will live in urban areas and human civilization in the city.[6] The city will grow and develop according to the dynamics of the economy, population, and social culture. Urban problems are increasingly complex and increasing. Problems are not only in physical form, but encompassing people and society. Kamil declares that Indonesia in the future can only be saved by human beings. Where urban improvement and implementation activities are implemented taking into account the sustainability of life and the future of human civilization in the city.

Medan is the third largest city in Indonesia by population, having the same problem. Rapid urban growth is characterized by population growth, availability of adequate facilities and infrastructure, wide and diverse employment, and rapid development of social, economic and cultural life. And this condition has an impact on the growth of urban settlements. Settlements in Indonesia developed formally and informally in locations directly related to the downtown area or other supporting areas.[7] Formal settlements are generally owned and occupied by middle and high-income communities. Meanwhile, informal settlements are inhabited by low-income communities. Low-income communities actually have limitations in getting a decent board. These communities will look for illegal lands to live and live in society. Because the settlement for the marginal is not just a place for shelter and gathering but also a place of business, a social event, and various multi-dimensional activities.[8]

Kampong Aur as a study area is a mix of formal and informal settlements along the Deli River, Medan. Deli River which divides the city center into a place that is not interesting to visit or be seen. Because of the river basin area has been polluted by a pile of rubbish and a slum of informal settlements. Most of the riverside in Medan City does not geographically from the city's features because the river is used as the back of the city that is not utilized optimally.

The problem of urban settlements in almost all developing countries is not an easy thing to solve. Regulations, policies, and evaluations related to economic, social and environmental sustainability should be carefully considered and thoroughly devoid of the community as a benchmark for planning and design, and an active role in decision-making.

Therefore, this paper was conducted as a preliminary study aimed at understanding, identifying, and looking at settlement problems in Kampong Aur, as well as finding the right solution, with a sustainable and humane approach. The main issue is having a reliable approach that can improve the quality of life of the riverside settlements. At next level of study, it becomes a baseline to planning and design with considering the existing condition of settlement - poverty, health problems, and poor living condition. The study was conducted by collecting data from various secondary sources, such as planning documents, an official site from the local government, previous studies, and aerial photographs. The primary data collection derived from observation for the formal and informal riverside settlements condition. The data obtained were elaborated and analyzed using a qualitative descriptive method. 


\section{An overview of riverside settlement}

\subsection{Cities and settlements}

The city is a center of activity and community life. The city is identical with social, economic, and environmental problems. These three are the basic pillars of the city that should grow and develop in a balanced way with an integrated approach. The developments of the city in general only focus on economic aspects. Social and environmental aspects, which are related to residence, are often underpaid.

The construction of housing for the masses in Indonesia is massively passive and static. So far the role of government only as a provider is not an enabler. The houses and settlements available have not been planned through a humane approach and according to the needs of the community.

Community involvement in the planning and design of urban settlement environments is a new alternative in bridging between government, planners and the community itself. With the active role of the community will create a sense of belonging so that the motivation to maintain and improve the environment will increase.[9]

Rapid population growth without equitable housing and infrastructure development is occuring in almost all developing countries. This condition is obviously in low-income communities living in urban areas with inadequate infrastructure, service, and environmental facilities. These people choose to live in legal and illegal urban lands, with formal or informal environments. And often the existing settlements ignore aspects of good health, comfort, and environmental quality. Meanwhile, formal settlements that provide better housing facilities are economically inaccessible to low-income communities due to price mechanisms that do not meet the standards of community life at this level.

The problems of urban settlements are inseparable from the context of slums, informal and low-income communities. The problem of informal settlements can be seen as a result of many influencing factors, and in many urban scenarios, informality is regarded as illegal. A consequence of their commonly perceived illegality, informal settlements, exist outside the formal frameworks - both socially and economically slum dwellers often lack rights to their homes, political recognition, and services from their government.[10] Rosmarin \& Connor also quoted that informality should be seen not solely a symptom of poverty - but rather as an alternative and potentially superior method of creating our urban environments.

\subsection{Informality of riverside settlements}

Riverside settlements are characterized by houses built on river borderline with simple materials and construction. Settlements are often not equipped with good sanitation, water supply, drainage and electricity systems. People living by the river and use it as a waste disposal, bathing, and washing, and household disposal systems that are not equipped septic tank. The distance between buildings is close so the occupancy does not get good light and the wind all day, so the house is not healthy and comfortable to live in. Riverside settlements are identical to disaster-accessible locations, such as the risk of floods, fires, and earthquakes.

Riverside settlements are chosen by the community as the nearest alternative land to work and socio-cultural activities that are comfortable for low-income people. In principle, people living on the riverside have an understanding and a desire to maintain their environment. However, cooperation between the community and local government needs to be improved in order to facilitate the needs and problems of the community regarding the quality of the urban settlement environment. In addition, the level of understanding and 
community life, as well as the flow of urbanization supported by loose regulation resulted in these settlements continuing to grow along the riverside.

\subsection{Riverside sustainability in the future}

Development of urban settlements, especially on the riverside, has been done in many places in the world. Activities are undertaken from eviction, providing low-cost housing, relocation, slum upgrading, land sharing, and lending to low-income communities to obtain a proper dwelling. Development activities are conducted between government and non-government organizations (NGOs), Community Based Organizations (CBOs), and local communities. Repair of slums consists of improvements in infrastructure including improvements to toilets and walkways, street lighting, drainage and water supplies.[11]

The most prominent settlement improvement in Indonesia is the Kampung Improvement Program (KIP).[12] The objective of the project is to provide access to physical infrastructure such as roads, paths, drainage, waste systems, water supply and social infrastructure such as schools and health centers for the poor living in informal settlements.

\section{The Deli riverside of Medan}

\subsection{Medan at a glance}

Medan City is the third largest city in Indonesia, located in North Sumatra Province. Medan City is bordered by Aceh Province and West Sumatra Province. The city of Medan, as one of the most important regional economic centers on the island of Sumatra, has a strategic position, function, and role as the main gateway for regional and international trade and financial services activities in western Indonesia. The strategic city position is supported by the availability of airports and seaports and other urban infrastructure and utilities.

The characteristics of the region are $265.10 \mathrm{~km} 2$ or $3.6 \%$ of the total area of North Sumatra Province. Administratively, Medan City is bordered by the Malacca Strait in the north, and borders on Deli Serdang Regency in the east, west, and south. The area of Medan City is accessible to flooding and it causes the geographical position of the city which is located at an altitude of $2.5-5.0 \mathrm{M}$ above sea level with relatively flat topography with a slope of $0-3 \%$.

Medan City is hydrologically influenced and surrounded by several major rivers and branch such as Percut River, Deli River, Babura River, Belawan River and other rivers. The rivers passing in Medan City not only affect the physical form, space, and environment but also affect the development pattern of Medan City. The rivers are still used by the community as one source of water that lives in the area around the river. In addition, these rivers also serve as the main drainage in the framework of flood control, as well as rainwater disposal. As a result, river functions tend to be more limited due to silting and environmental degradation. And this becomes a problem for the city of Medan.

The population of Medan City until 2009 is estimated to reach 2.1 million people with an average population growth of $1.1 \%$ per year. The projection of population growth rate of Medan City until 2015 is about $1.07 \%$ per year.[13] The highest population growth is caused by the rate of urbanization. The high rate of urbanization due to the city of Medan is an economic attraction for people in its hinterland. As population increases, the population density increases to 8.001 life $/ \mathrm{Km}^{2}$. The density of the population is relatively high and can cause an imbalance between the carrying capacity and urban environment less than optimal.

The attempt to provide housing for low-income communities in the city of Medan has not been comparable with the number of people who still need a house that is habitable, resulting in the growth of housing/slums. Currently, slum areas in Medan City are estimated 
to reach $22.5 \%$ of the total area of Medan City which consists of 88.166 housing units or $16.87 \%$ of the total existing houses in Medan City. Slum areas are spread in 145 villages and are generally located on the riverside and railroads in the city center.

\subsection{Riverside settlements along Deli River}

In early days of the Medan City development, the Deli River perform as a pulse of trade to other areas, namely as a transportation route in trading activities. At that time, the Deli River became a benchmark for the development of Medan City. Medan city grew and developed by the crossing of Deli River and Babura River. These two rivers became a busy traffic line and developed into a transit port of traders, in the past. And the river affects the historical, cultural and social development of the people of Medan City until now. However, the low appreciation of urban communities to rivers and the surrounding environment makes the river decrease water quality and the environment.

The Deli River is located in Medan Maimoon sub-districts of Medan City. The Medan Maimoon sub-district is one of the 21 sub-districts of Medan City that is located in the city center, near the center of Medan City Government. It covers a $3.342 \mathrm{Km}^{2}$, with borders of; Medan Polonia sub-district in the West, Medan Kota sub-district in the East, Medan Johor sub-district in the South, and Medan Barat sub-district in the North. There are 66 cluster associations and 6 neighborhood associations. According to 2012 census data, the Medan Maimoon sub-district has 39,581 inhabitants belonging to 137 households.[14] The study area is one part of 6 neighborhood association in Medan Maimoon sub-district which called Kampong Aur.

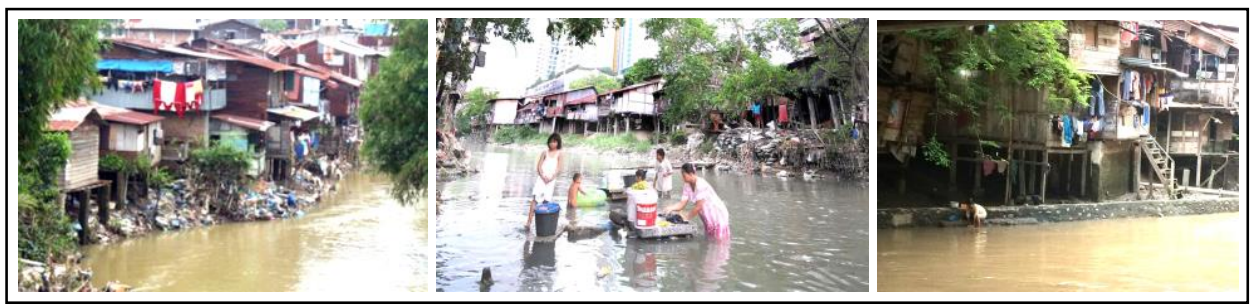

Fig. 1. Riverside settlements along Deli River

Source: http://google.co.id, accessed on 24th April 2017

\subsection{The study area - Kampong Aur}

Kampong Aur is one of the urban villages classified as slum settlement.[15] Kampong Aur consists of four neighborhoods that are part of Medan Maimoon sub-district, with an area of $34.2 \mathrm{Ha}$, and a population of 715 people with a density number of 21 .

The total number of buildings in Kampong Aur is 320 units and $26 \%$ of it is well ordered. Kampong Aur is known as a settlement with a high occupancy density of 45 units / Ha. And only $80 \%$ of housings have the condition of the roof, floors, walls, according to technical requirements.

The existing infrastructure of Kampong Aur is quite good. Environmental accessibility has been complemented by a proper road as well as technical requirements. In addition to the high density of the building, Kampong Aur is also known as a flood-accessible area due to the Deli River which overflowed in the rainy season, where almost all neighborhoods are flooded and drainage systems are not able to anticipate the condition. The availability of environmental drainage is sufficient, but it is necessary to review the appropriate design for Kampong Aur's environmental conditions. Electricity and water infrastructure is well available and accommodated by the local government. More than $90 \%$ of people in 
Kampong Aur have been served by clean water and electricity. Meanwhile, waste management and fire protection still need special attention and handling.

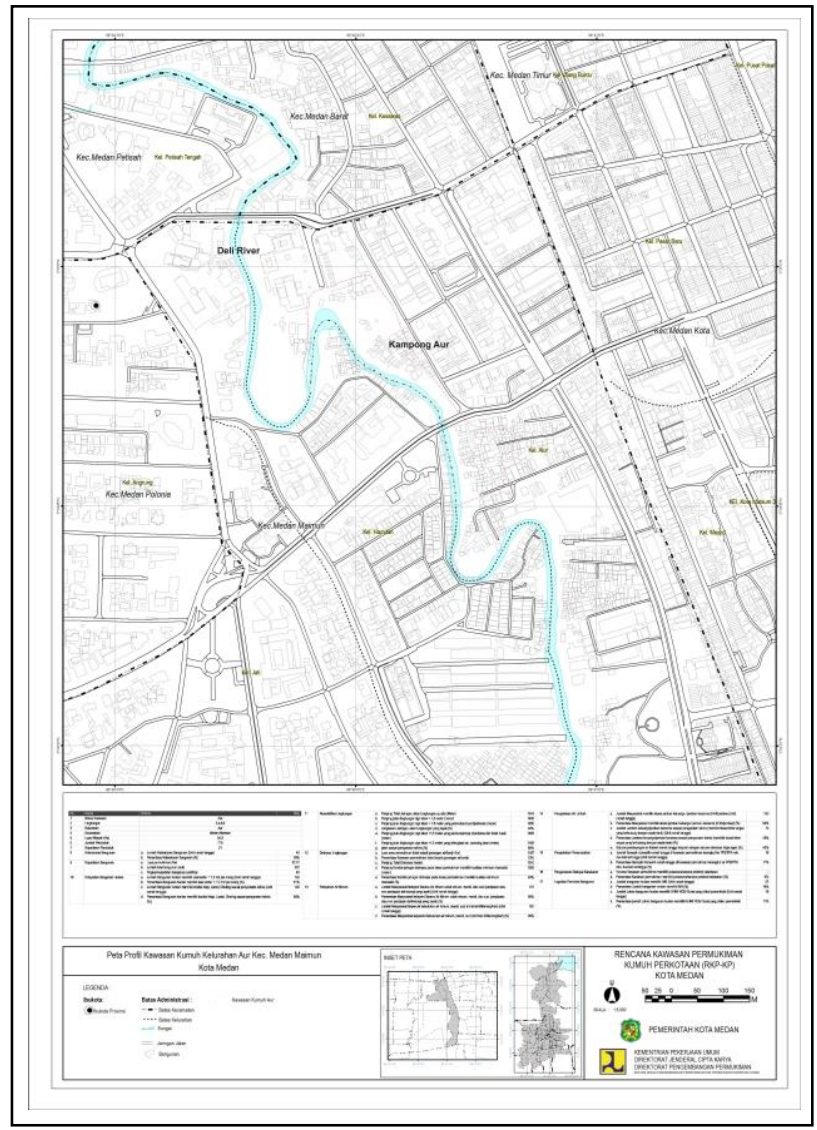

Fig. 2. Map of study area

Source: RKP-KP Pemerintah Kota Medan, 2016

\section{Problem: cause and approach}

The problems of urban settlement in the city center, such as Kampong Aur, have their own character that can be observed in the physical environment, land tenure, public facilities, economic features and livelihoods, and social and culture conditions.

\subsection{Land tenure}

From the total of 320 occupations, only $11 \%$ have legal land tenure, and the rest do not have its certificates. Based on information in the field, the land tenure of Kampong Aur in the past is owned by the Deli Sultanate and one of the largest entrepreneurs in Medan City, namely Chong A Fie. Possibly, the condition becomes one of the reasons behind the arrangement of Kampong Aur settlement area has not been done properly.

According to land tenure, it is necessary to establish communication between various parties such as academics, community, local or regional authorities, non-governmental organizations (NGO's), which are integrated through the efforts of land consolidation. Finally, it will ensure the security and comfort of living in the community, development 
activities, and to improve the quality of the environment and preservation of natural resources.

\subsection{Physical environment}

The physical condition of the Kampong Aur environment has diverse characteristics. The physical form of the settlement is a permanent house which is one-storeyed and two. While the physical form at the fringe, which is on the river borderline, is identified as slum area that used materials construction such as wood, zinc, and plywood. Physically, the characteristics of the settlement area contoured with the lowest elevation orientation on the riverside. The density of buiding, irregular, and contoured arrangements produce a slum settlement. The approach of land consolidation can be improved the physical condition of a better environment for the sustainability of the community.

Housing in Kampong Aur can not be said a proper dwelling because of the settlement area is not well ordered. In addition, there is a decline in the quality capability of environmental facilities and infrastructure caused by the low maintenance and development of infrastructure after it was built. This is concerned with the performance of the community is low. This problem is a great task for the local government because of there is no specific reference to addressing the environmental issues of the settlements in Kampong Aur.

The improvement of the physical environment, both settlements, and housing, in Kampong Aur, can be done through cooperative design approach or known as co-design approach. It is an approach to design attempting to actively involve all parties (e.g. settlers, academics, NGO's, local authorities, investors, private sectors) in the design process to help ensure the result meets their needs and is usable.

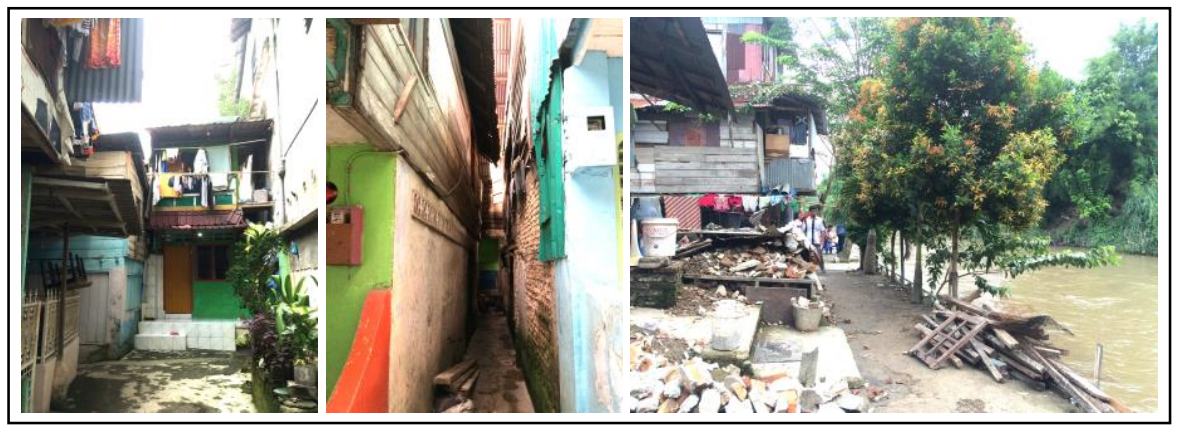

Fig. 3. Physical condition of settlements and environment

\subsection{Public facilities}

The establishment of public facilities in Kampong Aur are mosques and religious schools or madrasah. Open space as a performance of people's social interaction is determined in the roads, porch, riverside, and gathering hall of resident house. Public utilities such as water, electricity, drainage systems, and waste disposal mechanisms are lack. For example, not every house has a septic tank. Septic tank also has the same sewage system as the environmental drainage system. The existing of the drainage system accommodates all housing and environmental disposal systems, such as rainwater disposal and solid waste. The locked structure of drainage system causes an overflow of water when flooding which is not possible to accommodate trash and flooded in the drain. It causes poor living conditions for local residents.

Public facilities in the settlement need to be renewal and reconstruction. A passed narrow road path by various vehicles causes uncomfortable track road to be through. For example, pavement systems can be renewal into porous pavements that can absorb water into 
the ground so that when a flooding through the road, it can be absorbed by the ground well. In addition, the road with a different level of height should be made up a ladder so that the road path comfortable to pass. Other efforts to prevent overflow from flooding into residential areas are should be greening along the riverside. And slum settlements along the river borderline can be suggested to be relocated to an appropriate place. By the relocation, planning and design activity should not be neglected the nature of habit of community in the previous settlements. And it should be done by considerate and humane.

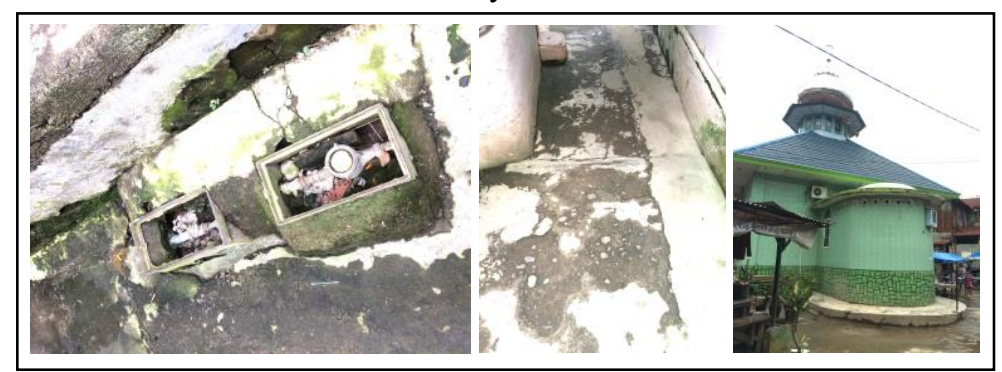

Fig. 4. Public facilities of Kampong Aur

\subsection{Economic features and livelihoods}

Kampong Aur is a strategic urban village located in the inner city and it is a wider riverside settlement than other. This condition allows the community to be able to move from and to the location of work. In addition, the location is very close to city government center, traditional markets, and commercial activity centers. These provide opportunities for different sources of livelihoods. The main sources of livelihood are street vendors, carrying market stuff for the consumers, parking keepers, casual laborers, sewing laborers, warung or small stalls, construction workers, and government employees.

Kampong Aur community is very active in various social activities related to the development of family welfare. They have an active community group. Through these community groups, all parties such as private companies, academics, and government agencies have a strong interest in providing training, counseling, and physical actions to improve community's economic lives. The activities were conducted together with local women's groups with various types of activities, including knitting training, inorganic fertilizer training, cooking, gardening of vegetable plants, and others. With the efforts made by all parties are expected the welfare of the community and insight into the source of livelihood is increasing.

Home economic, such as small stalls, should be trained and facilitated to obtain a proper workplace for an attractive and comfortable environment. Another effort that can be done is to build the people into a tourism-conscious community. The activity, both economics, social, and cultural, encouraged income opportunity to invite local tourists and non-local to visit the settlement.

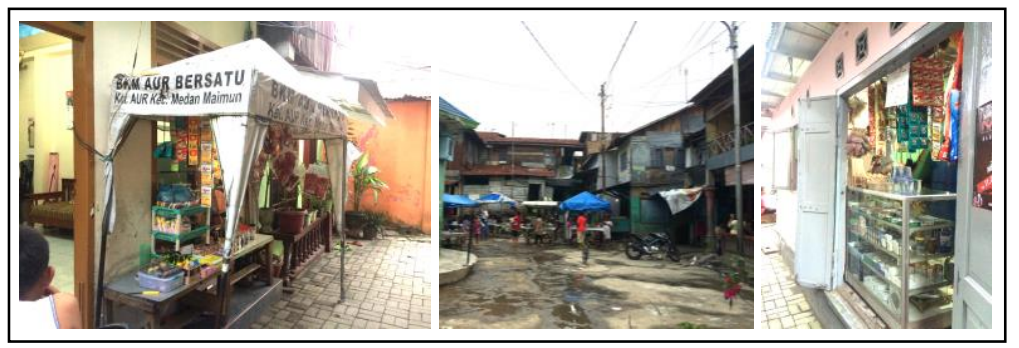

Fig. 5. Economic activities around the environment 


\subsection{Socio cultural conditions}

In general, the community in informal settlements lives with threat conditions that affect the environment and itself. River as a natural resource used for bathing, clothing, and even toilet. Nevertheless, the social bonds between peoples are well established with the physical intimacy, common problems of life, and their social character.

However, Kampong Aur does not have the facility to engage in social interaction, especially for children, ceremonies and religious activity. Kampong Aur communities are the low-income people with a poor living condition. There are children of school age who can not continue their education to the next level because of a cost. So, it becomes a vandalism and drugs activity among it. People, in general, are apathetic to their life. However, some of the people in Kampong Aur neighborhood are engaged in positive activities with the external.

To maintain a positive social life can be done through counseling continuously, open an economic opportunities, creating interest activities for children, young, and woman. Activities need to be sustainably maintained so that it becomes a culture and profitable for the communities. For example, organize kampong festivals, mural festivals, as well as being environmental agents around. All activities are the participation of all levels of community and outside agent roles as facilitators and supported by the establishment of kampong councils as respected community agents.

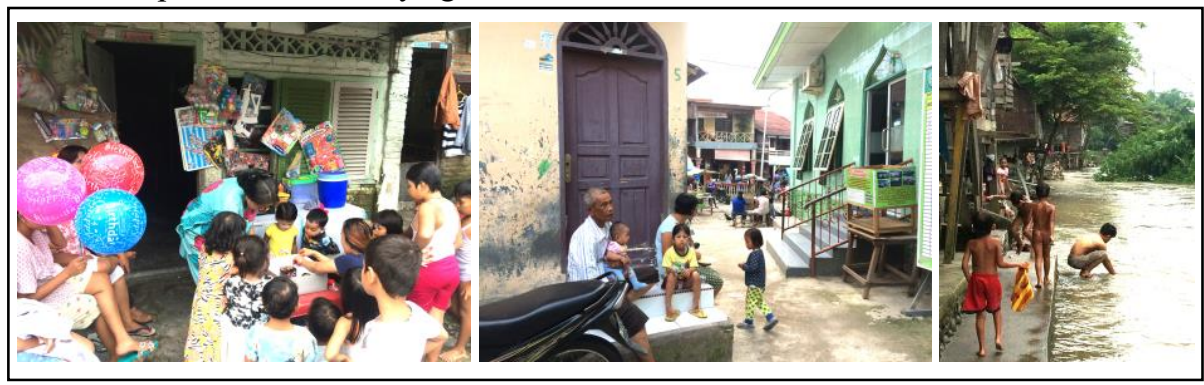

Fig. 6. Social interaction among people around the environment

\section{Conclusions}

The Deli riverside problem in the study area is low-income community and migrants from rural. This community lives in a forbidden location in the middle of the city because of the urge of the rapid development of the city. The need for a place to live close to work sites, public transport, and activity centers has also become the main reason. To obtain a livable house in a formal settlement is not a priority because of an inability economically of the communities.

Poor living conditions and poverty is a common feature of informal settlements with chain reactions among different socio economic, political, and environmental factors. And evictions are not the acceptable method to solve informal settlement problems. By evicting it means violating human rights and the poor are the most affected victims.

A possible approach is a combination of integral improvement and relocation activities for the sustainability of the riverside. The relocation, especially in the borderline, can be moved to a new location around the settlements. And the settlement improvement can be done through renewal by the participatory approach in planning and design. Through this approach, it is expected that communication gaps between the communities, local authorities, NGO's, private sectors, or investors, to determine policy, and financing can be well organized during the planning process. The proposed approach aims and focuses on the informal community interests so that they do not return to a poor living. Finally, increased quality of settlements will affect city life more humane and sustainable in the future. 


\section{References}

1. UN-Habitat. Housing the poor in Asian Cities: Quick guide 1, Published by UNESCAP, pp. 1-29 (2008)

2. UNCHS (United Nations Centre for Human Settlements). Challenge of slum, Global report on human settlements 2003, UN Habitat, Earthscan, London and Sterling, pp. 195-228 (2003)

3. et al, (2003)

4. T. Rosmarin, J. Connor. Lesson of Informality, Part I: 'A global phenomenon urban informality', Regular Spread, University of Melbourne, Melbourne School of Design, pp. 12-15 (2016)

5. Dick, 2002 quoted by S., A.A. Sari. The emergence of informal riverside settlements and challenge for planning: The case of Kali Mas in Surabaya, Indonesia, Proceeding: The $3^{\text {rd }}$ International Seminar on Tropical Eco Settlements; Urban Deprivation: A Challenge to Sustainable Urban Settlements, A-14, pp. 137-148 (2012)

6. http://www.youtube.com/watch? $\mathrm{v}=\mathrm{hDw}-\mathrm{Tq} 1 \mathrm{anKU}$, TEDxJakarta : Ridwan KamilCreativity and design for social change in cities, accessed on 6 March (2017)

7. N. Hamidah. "Kampung sebagai model permukiman berkelanjutan di Indonesia", INERSIA. J. V 12 N 2: 24-34 (2017)

8. E. Budiharjo. Percikan masalah : Arsitektur, perumahan, perkotaan. Penerbit : Gadjah Mada University Press, Yogyakarta, pp. 67-68 (2006)

9. $\quad$ et al, pp. 54 (2006)

10. Mc Kean, 2009 quoted by T. Rosmarin, J. Connor. Lesson of informality, Part I: 'A global phenomenon urban informality', Regular Spread, University of Melbourne, Melbourne School of Design, pp. 12-15 (2016)

11. UNESCAP, 2003 quoted by S., A.A. Sari. The emergence of informal riverside settlements and challenge for planning: The case of Kali Mas in Surabaya, Indonesia, Proceeding: The 3rd International Seminar on Tropical Eco Settlements; Urban Deprivation: A Challenge to Sustainable Urban Settlements, A-14, pp. 137-148 (2012)

12. S., A.A. Sari. The emergence of informal riverside settlements and challenge for planning: The case of Kali Mas in Surabaya, Indonesia, Proceeding: The 3rd International Seminar on Tropical Eco Settlements; Urban Deprivation: A Challenge to Sustainable Urban Settlements, A-14, pp. 137-148 (2012)

13.

Peraturan Pemerintah Kota Medan Nomor 14 Tahun 2011 Tentang Rencana Pembangunan Jangka Menengah Daerah (RPJMD) Kota Medan Tahun 20112015, Pemko Medan (2011)

14. http://pemkomedan.go.id/hal-medan-maimun.html, accessed on $30^{\text {th }}$ March (2017)

15. Rencana Kawasan Permukiman Kumuh Kota Medan (RKP-KP), Kementrian PU Direktorat Jenderal Cipta Karya ; Direktorat Pengembangan Permukiman (2016) 